\title{
The effect of ventilator-associated pneumonia on the prognosis of intensive care unit patients within 90 days and 180 days
}

Wenjuan Luo ${ }^{*}$, Rui Xing and Canmin Wang

\begin{abstract}
Background: Mechanical ventilation (MV) is often applied in critically ill patients in intensive care unit (ICU) to protect the airway from aspiration, and supplement more oxygen. MV may result in ventilator-associated pneumonia (VAP) in ICU patients. This study was to estimate the 90-day and 180-day mortalities of ICU patients with VAP, and to explore the influence of VAP on the outcomes of ICU patients.
\end{abstract}

Methods: Totally, 8182 patients who aged $\geq 18$ years and received mechanical ventilation (MV) in ICU from Medical Information Mart for Intensive Care III (MIMIC III) database were involved in this study. All subjects were divided into the VAP group $(n=537)$ and the non-VAP group $(n=7626)$ based on the occurrence of VAP. Clinical data of all participants were collected. The effect of VAP on the prognosis of ICU patients was explored by binary logistic regression analysis.

Results: The results delineated that the 90-day mortality of VAP patients in ICU was 33.33\% and 180-day mortality was $37.62 \%$. The 90-day and 180-day mortality rates were higher in the VAP group than in the non-VAP group. After adjusting the confounders including age, ethnicity, heart failure, septicemia, simplified acute physiology score II (SAPSII) score, sequential organ failure assessment (SOFA) score, serum lactate, white blood cell (WBC), length of ICU stay, length of hospital stay, length of ventilation, antibiotic treatment, Pseudomonas aeruginosa (P.aeruginosa), methicillin-resistant Staphylococcus aureus (MRSA), other pathogens, the risk of 90-day and 180-day mortalities in VAP patients were 1.465 times $(\mathrm{OR}=1.465,95 \% \mathrm{Cl}$ : 1.188-1.807, $P<0.001)$ and 1.635 times $(\mathrm{OR}=1.635,95 \% \mathrm{Cl}$ : $1.333-2.005, P<0.001)$ higher than those in non-VAP patients, respectively.

Conclusions: Our study revealed that ICU patients with VAP had poorer prognosis than those without VAP. The results of this study might offer a deeper insight into preventing the occurrence of VAP.

Keywords: Ventilator-associated pneumonia, Prognosis, Intensive care unit

\footnotetext{
* Correspondence: wenjuanluooo@outlook.com

Department of Critical Care Medicine, Guangdong Second Provincial General Hospital, No.466 Xingang Middle Road, Guangzhou 510000, Guangdong, China
}

(c) The Author(s). 2021 Open Access This article is licensed under a Creative Commons Attribution 4.0 International License, which permits use, sharing, adaptation, distribution and reproduction in any medium or format, as long as you give appropriate credit to the original author(s) and the source, provide a link to the Creative Commons licence, and indicate if changes were made. The images or other third party material in this article are included in the article's Creative Commons licence, unless indicated otherwise in a credit line to the material. If material is not included in the article's Creative Commons licence and your intended use is not permitted by statutory regulation or exceeds the permitted use, you will need to obtain permission directly from the copyright holder. To view a copy of this licence, visit http://creativecommons.org/licenses/by/4.0/ The Creative Commons Public Domain Dedication waiver (http://creativecommons.org/publicdomain/zero/1.0/) applies to the data made available in this article, unless otherwise stated in a credit line to the data. 


\section{Background}

Mechanical ventilation (MV) is often applied in critically ill patients in intensive care unit (ICU) [1]. MV may result in various complications and bring substantial risks in ICU patients [2]. Ventilator-associated pneumonia (VAP) is a common nosocomial infection in ICU occurring $>48 \mathrm{~h}$ after endotracheal intubation in patients receiving MV [3]. The most common clinical symptoms of VAP patients were fever, changed white blood cell count, altered sputum characteristic, appearance of a causative agent [4]. VAP can be considered when new pulmonary infiltrates appear, and diseases such as pulmonary edema, pulmonary tumors, and pulmonary infarction have been excluded [5].

VAP is associated with high morbidity and mortality. Previous researchers have identified that the incidence of VAP is approximately 8 to $28 \%$ [6]. Although the tendency of incidence was decreased in recent years, VAP is still a heavy burden to the patients and society. The occurrence of VAP may lead to the prolongation of $\mathrm{MV}$ use, the consumption of antibiotics, and also increase of length of stay and the burden of hospitalization costs [7]. Multiple lines of evidences revealed that the prognosis of VAP patients is very poor [8]. The mortality of VAP was recorded to be $19.4-51.6 \%$ in China and 14 to $50 \%$ in other countries $[9,10]$. Critically ill patients are always admitted to the ICU and present high mortality risk [11]. VAP in ICU has an incidence of 13.5 to $23 \%$, and accounts for one of the common causes of morbidity and mortality [12, 13]. Currently, the effect of VAP on the prognosis of ICU patients was still not fully elucidated. A detailed understanding of VAP may have important implications for improving the outcomes of patients with VAP. The aim of this study was to estimate the 90-day and 180-day mortalities of ICU patients with VAP, and to explore the influence of VAP on the outcomes of ICU patients. The results of our study might provide a reference for clinicians to make timely intervention for prevent the occurrence of VAP in ICU.

\section{Methods \\ Study population}

Medical Information Mart for Intensive Care III (MIMI C III) database (https://mimic.physionet.org/) is a freely accessible database comprising the data associated with health of about 60,000 patients staying in the critical care units of Beth Israel Deaconess Medical Center from 2001 to 2012 [14]. In our study, the data about 8182 patients receiving $\mathrm{MV}$ in ICU was extracted from MIMIC III database. Those aged $<18$ years were excluded $(n=$ 19). Finally, 8163 subjects were involved. All subjects were divided into the VAP group $(n=537)$ and the nonVAP group ( $n=7626)$ based on the occurrence of VAP. The diagnosis of VAP was in line with the criteria of the American Centers for Disease Control and Prevention (CDC) [15]. The CDC algorithm defines probable VAP include clinically nuanced, subjective criteria such as worsening gas exchange, change in the character of sputum, and new or progressive and persistent infiltrates (Table 1) [16]. The construction of MIMIC-III database was approved by the Ethics Review Board of the Beth Israel Deaconess Medical Center and all private information has been carried out the desensitization.

\section{Data extraction}

Clinical data of all participants were collected from MIMIC III database based on the clinical experience and other literatures have published previously with a relevant topic. The data included age (years), gender, ethnicity (White, Asian, Black, Hispanic/latino and Other), red cell distribution width (RDW), white blood cell (WBC, $10^{9} / \mathrm{L}$ ), international normalized ratio (INR), length of ICU stay (day), length of hospital stay (day), length of ventilation (hour), antibiotic treatment (none,

Table 1 Centers for Disease Control and Prevention's clinical surveillance definition for VAP

\begin{tabular}{|c|c|}
\hline \multirow{3}{*}{$\begin{array}{l}\text { Radiologic criteria (two or more serial radiographs with } \\
\text { at least one of the following) }\end{array}$} & 1. New or progressive and persistent infiltrate \\
\hline & 2. Consolidation \\
\hline & 3. Cavitation \\
\hline \multirow[t]{3}{*}{ Systemic criteria (at least one) } & 1. Fever $\left(>38^{\circ} \mathrm{C}\right.$ or $\left.>100.4^{\circ} \mathrm{F}\right)$ \\
\hline & 2. Leukopenia $\left(<4000 \mathrm{WBC} / \mathrm{mm}^{3}\right)$ or leukocytosis $\left(\geq 12,000 \mathrm{WBC} / \mathrm{mm}^{3}\right)$ \\
\hline & 3. For adults $\geq 70$ years old, altered mental status with no other recognized cause \\
\hline \multirow[t]{4}{*}{ Pulmonary criteria (at least two) } & $\begin{array}{l}\text { 1. New onset of purulent sputum, or change in character of sputum, or increased } \\
\text { respiratory secretions, or increased suctioning requirements }\end{array}$ \\
\hline & $\begin{array}{l}\text { 2. Worsening gas exchange (e.g., desaturations, increased oxygen requirements, or increased } \\
\text { ventilator demand }\end{array}$ \\
\hline & 3. New onset or worsening cough, or dyspnea, or tachypnea \\
\hline & 4. Rales or bronchial breath sounds \\
\hline
\end{tabular}


single antibiotic, and combined antibiotics), pathogens species [Acinetobacter baumannii (A.baumannii), Pseudomonas aeruginosa (P.aeruginosa), methicillinresistant Staphylococcus aureus (MRSA), Klebsiella pneumoniae (K.pneumoniae), methicillin-sensitive Staphylo coccus aureus (MSSA), Escherichia coli (E. coli), and Other pathogens], serum lactate $(\mathrm{mmol} / \mathrm{L})$, history of chronic obstructive pulmonary disease (COPD), diabetes, septicemia and heart failure, simplified acute physiology score II (SAPSII) score, sequential organ failure assessment (SOFA) score, 90-day mortality, and 180day mortality.

\section{Statistical analysis}

All statistical analyses were completed by $\mathrm{R} 4.0 .2$ software. Wilcoxon rank sum test was used for comparison of quantitative variables between the VAP group and non-VAP group, while chi-square test or Fisher's exact test were used for comparing the qualitative variables. The effect of VAP on the prognosis of ICU patients was explored by binary logistic regression analysis with the occurrence of VAP as the independent variable and death within 90/180 days as the dependent variables after adjusting the confounders (age, ethnicity, heart failure, septicemia, SAPSII score, SOFA score, serum lactate, WBC, length of ICU stay, length of hospital stay, length of ventilation, antibiotic treatment, P.aeruginosa, MRSA, other pathogens). Two-side test was used in this study, and $P<0.05$ was considered statistically significant.

\section{Results}

\section{Clinical characteristics of all subjects}

In total, 8182 patients receiving MV in ICU were involved in our study. After excluding 19 patients who

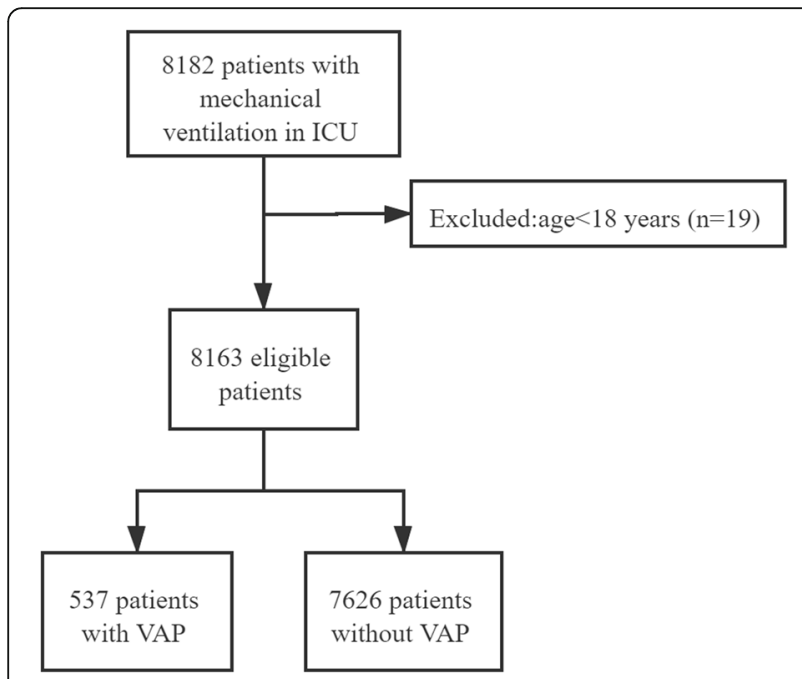

Fig. 1 The screen process of all the subjects in our study aged < 18 years, 8136 subjects were involved in this study, including 537 (6.58\%) in the VAP group and 7626 $(93.42 \%)$ in the non-VAP group. The screening process of patients was shown in Fig. 1. Among all patients, the average age of all participants was $64.06 \pm 16.28$ years, and 4940 (60.52\%) patients were males.215 (2.63\%) people were Asians, 563 (6.90\%) people were Black, 298 (3.65\%) people were Hispanic/latino and 5902 (72.30\%) people were White. 861 (10.55\%) subjects had COPD, 1493 (18.29\%) had septicemia, 2027 (24.83\%) had and 2107 (25.81\%) had heart failure. The 90-day and 180-day mortality rates were 24.61 and $26.60 \%$, respectively (Table 2).

\section{Comparison of characteristics between VAP group and non-VAP group}

After comparing the clinical characteristics of ICU patients in the VAP group and non-VAP group, we found that the age of patients in the VAP group was younger than the non-VAP group (62.29 years vs 64.19 years, $\mathrm{t}=2.260, P=0.009$ ), and the proportions of heart failure $\left(32.03 \%\right.$ vs $25.37 \%, X^{2}=11.607, P<$ $0.001)$, septicemia $\left(31.47 \%\right.$ vs $17.36 \%, X^{2}=66.828$, $P<0.001)$, antibiotic treatment $(\mathrm{Z}=18.883, P<0.001)$, P. eruginosa $(P<0.001)$, MRSA $\left(4.66 \%\right.$ vs $2.05 \%, \chi^{2}=$ $15.760, P<0.001)$ and other pathogens $(14.90 \%$ vs 9.05\%, $\left.X^{2}=20.094, P<0.001\right)$ were in the VAP group were higher than non-VAP group. The SAPSII score (41.00 vs $38.00, \quad \mathrm{Z}=3.679, P<0.001)$, SOFA score (7.581 vs $7.096, \mathrm{t}=-3.040, P=0.002$ ), serum lactate $(1.80 \mathrm{mmol} / \mathrm{L}$ vs $1.60 \mathrm{mmol} / \mathrm{L}, \mathrm{Z}=2.773, P=0.006)$, WBC $\left(12.0010^{9} / \mathrm{L}\right.$ vs $11.5010^{9} / \mathrm{L}, \mathrm{Z}=2.068, P=$ $0.039)$ in the VAP group were higher than the nonVAP group. The length of ICU stay (12.69 days vs 2.99 days, $\mathrm{Z}=27.865, P<0.001)$, length of hospital stay ( 18.79 days vs 8.09 days, $\mathrm{Z}=21.875, \quad P<0.001$ ) and length of ventilation $(216.47 \mathrm{~h}$ vs $20.86 \mathrm{~h}, \mathrm{Z}=$ 27.780, $P<0.001)$ in the VAP group were higher than in the non-VAP group. The ethnic distribution was different between the VAP group and non-VAP group $\left(X^{2}=15.423, P=0.004\right)$. the 90 -day mortality $(33.33 \%$ vs $\left.24.00 \%, X^{2}=23.569, P<0.001\right)$ and 180 -day mortality $\left(37.62 \%\right.$ vs $\left.25.82 \%, X^{2}=35.762, P<0.001\right)$ in the VAP group were higher than in the non-VAP group. (Table 2).

The influence of VAP on the prognosis of ICU patients After adjusting for confounders such as age, ethnicity, serum lactate, septicemia, heart failure, SAPSII score, SOFA score, WBC, length of ICU stay, length of hospital stay, length of ventilation, antibiotic treatment, P.aeruginosa, MRSA, and other pathogens, the results of multivariate logistic regression analysis showed that the 90day mortality risk of VAP patients was 1465 times $(\mathrm{OR}=$ 
Table 2 Comparison and single logistic analysis for Characteristics of VAP and Non-VAP patients

\begin{tabular}{|c|c|c|c|c|c|c|c|}
\hline Characteristic & $\begin{array}{l}\text { All patients }(n= \\
\text { 8163) }\end{array}$ & $\begin{array}{l}\text { Non-VAP } \\
\text { Patients } \\
(n=7626)\end{array}$ & $\begin{array}{l}\text { VAP Patients } \\
(n=537)\end{array}$ & Statistical magnitude & $P$ & OR $(95 \% \mathrm{Cl})$ & Logit-P \\
\hline Age, Mean $\pm S D$ & $64.06 \pm 16.28$ & $64.19 \pm 16.22$ & $62.29 \pm 16.98$ & $t=2.620$ & 0.009 & $\begin{array}{l}0.993(0.988- \\
0.998)\end{array}$ & 0.009 \\
\hline Gender, n(\%) & & & & $x^{2}=0.132$ & 0.716 & & \\
\hline Female & $3223(39.48)$ & $3007(39.43)$ & $216(40.22)$ & & & Ref & \\
\hline Male & $4940(60.52)$ & $4619(60.57)$ & $321(59.78)$ & & & $\begin{array}{l}0.967(0.809- \\
1.156)\end{array}$ & 0.716 \\
\hline Ethnicity, n(\%) & & & & $x^{2}=15.423$ & 0.004 & & \\
\hline White & $5902(72.30)$ & $5543(72.69)$ & $359(66.85)$ & & & Ref & \\
\hline Asian & $215(2.63)$ & $197(2.58)$ & $18(3.35)$ & & & $\begin{array}{l}1.411(0.861- \\
2.313)\end{array}$ & 0.172 \\
\hline Black & $563(6.90)$ & $515(6.75)$ & $48(8.94)$ & & & $\begin{array}{l}1.439(1.051- \\
1.971)\end{array}$ & 0.023 \\
\hline Hispanic/latino & $298(3.65)$ & $285(3.74)$ & $13(2.42)$ & & & $\begin{array}{l}0.704(0.400- \\
1.240)\end{array}$ & 0.225 \\
\hline Other & $1185(14.52)$ & $1086(14.24)$ & 99 (18.44) & & & $\begin{array}{l}1.408(1.116- \\
1.775)\end{array}$ & 0.004 \\
\hline COPD, n(\%) & $861(10.55)$ & $794(10.41)$ & $67(12.48)$ & $x^{2}=2.267$ & 0.132 & $\begin{array}{l}1.227(0.940- \\
1.601)\end{array}$ & 0.133 \\
\hline Heart failure, n(\%) & $2107(25.81)$ & $1935(25.37)$ & 172 (32.03) & $x^{2}=11.607$ & $\begin{array}{l}< \\
0.001\end{array}$ & $\begin{array}{l}1.386(1.148- \\
1.674)\end{array}$ & $<0.001$ \\
\hline Diabetes, n(\%) & $2027(24.83)$ & $1887(24.74)$ & $140(26.07)$ & $x^{2}=0.473$ & 0.492 & $\begin{array}{l}1.073(0.878- \\
1.309)\end{array}$ & 0.492 \\
\hline Septicemia, n(\%) & $1493(18.29)$ & $1324(17.36)$ & $169(31.47)$ & $x^{2}=66.828$ & $\begin{array}{l}< \\
0.001\end{array}$ & $\begin{array}{l}2.186(1.805- \\
2.647)\end{array}$ & $<0.001$ \\
\hline SAPSII score, $M\left(Q_{1}, Q_{3}\right)$ & $38.00(30.00,49.00)$ & $\begin{array}{l}38.00(30.00 \\
49.00)\end{array}$ & $41.00(31.00,52.00)$ & $Z=3.679$ & $\begin{array}{l}< \\
0.001\end{array}$ & $\begin{array}{l}1.009(1.003- \\
1.014)\end{array}$ & 0.002 \\
\hline SOFA score, Mean \pm SD & $7.128 \pm 3.581$ & $7.096 \pm 3.579$ & $7.581 \pm 3.585$ & $t=-3.040$ & 0.002 & $\begin{array}{l}1.037(1.013- \\
1.062)\end{array}$ & 0.002 \\
\hline Serum Lactate, $M\left(Q_{1}, Q_{3}\right)$ & $1.60(1.10,2.60)$ & $1.60(1.10,2.60)$ & $1.80(1.20,3.00)$ & $Z=2.773$ & 0.006 & $\begin{array}{l}1.051(1.011- \\
1.092)\end{array}$ & 0.013 \\
\hline$W B C, M\left(Q_{1}, Q_{3}\right)$ & $11.60(8.20,15.70)$ & $\begin{array}{l}11.50(8.10 \\
15.70)\end{array}$ & $12.00(8.70,16.20)$ & $Z=2.068$ & 0.039 & $\begin{array}{l}1.010(1.001- \\
1.018)\end{array}$ & 0.022 \\
\hline INR, $M\left(Q_{1}, Q_{3}\right)$ & $1.30(1.10,1.50)$ & $1.30(1.10,1.50)$ & $1.20(1.10,1.60)$ & $Z=-1.295$ & 0.195 & $\begin{array}{l}1.067(0.998- \\
1.141)\end{array}$ & 0.059 \\
\hline $\begin{array}{l}\text { Length of ICU stay, } M\left(Q_{1} \text {, }\right. \\
\left.Q_{3}\right)\end{array}$ & $3.17(1.61,6.98)$ & $2.99(1.48,6.06)$ & $12.69(7.69,20.81)$ & $Z=27.865$ & $\begin{array}{l}< \\
0.001\end{array}$ & $\begin{array}{l}1.140(1.128- \\
1.152)\end{array}$ & $<0.001$ \\
\hline $\begin{array}{l}\text { Length of hospital stay, } \\
M\left(Q_{1}, Q_{3}\right)\end{array}$ & $8.52(5.14,14.65)$ & $8.09(5.00,13.48)$ & $18.79(12.33,26.91)$ & $Z=21.875$ & $\begin{array}{l}< \\
0.001\end{array}$ & $\begin{array}{l}1.046(1.040- \\
1.052)\end{array}$ & $<0.001$ \\
\hline $\begin{array}{l}\text { Length of ventilation, } M\left(Q_{1} \text {, }\right. \\
\left.Q_{3}\right)\end{array}$ & $23.50(8.63,87.33)$ & $\begin{array}{l}20.86(7.85 \\
69.67)\end{array}$ & $\begin{array}{l}216.47(114.57 \\
351.26)\end{array}$ & $Z=27.780$ & $\begin{array}{l}< \\
0.001\end{array}$ & $\begin{array}{l}1.008(1.007- \\
1.008)\end{array}$ & $<0.001$ \\
\hline Antibiotic treatment, n(\%) & & & & $Z=18.883$ & $\begin{array}{l}< \\
0.001\end{array}$ & & \\
\hline None & $1266(15.51)$ & $1248(16.37)$ & $18(3.35)$ & & & Ref & \\
\hline Single antibiotic & $2623(32.13)$ & $2610(34.23)$ & $13(2.42)$ & & & $\begin{array}{l}0.346(0.169- \\
0.707)\end{array}$ & 0.004 \\
\hline Combined antibiotics & $4274(52.36)$ & $3768(49.41)$ & $506(94.23)$ & & & $\begin{array}{l}9.311(5.793- \\
14.963)\end{array}$ & $<0.001$ \\
\hline \multicolumn{8}{|l|}{ Pathogens species, n(\%) } \\
\hline A.baumannii & $6(0.07)$ & $5(0.07)$ & $1(0.19)$ & - & 0.335 & $\begin{array}{l}2.850(0.333- \\
24.400)\end{array}$ & 0.339 \\
\hline P.aeruginosa & $67(0.82)$ & $53(0.69)$ & $14(2.61)$ & - & $<$ & $3.825(2.108-$ & $<0.001$ \\
\hline
\end{tabular}


Table 2 Comparison and single logistic analysis for Characteristics of VAP and Non-VAP patients (Continued)

\begin{tabular}{|c|c|c|c|c|c|c|c|}
\hline Characteristic & $\begin{array}{l}\text { All patients }(n= \\
8163)\end{array}$ & $\begin{array}{l}\text { Non-VAP } \\
\text { Patients } \\
(n=7626)\end{array}$ & $\begin{array}{l}\text { VAP Patients } \\
(n=537)\end{array}$ & Statistical magnitude & $P$ & OR $(95 \% \mathrm{Cl})$ & Logit- $P$ \\
\hline & & & & & 0.001 & 6.939) & \\
\hline MRSA & $181(2.22)$ & $156(2.05)$ & $25(4.66)$ & $x^{2}=15.760$ & $\begin{array}{l}< \\
0.001\end{array}$ & $\begin{array}{l}2.339(1.519- \\
3.602)\end{array}$ & $<0.001$ \\
\hline K.pneumoniae & $61(0.75)$ & $54(0.71)$ & $7(1.30)$ & - & 0.120 & $\begin{array}{l}1.852(0.839- \\
4.090)\end{array}$ & 0.127 \\
\hline MSSA & $123(1.51)$ & $113(1.48)$ & $10(1.86)$ & $x^{2}=0.489$ & 0.484 & $\begin{array}{l}1.262(0.657- \\
2.423)\end{array}$ & 0.485 \\
\hline E. coli & $128(1.57)$ & $118(1.55)$ & $10(1.86)$ & $x^{2}=0.322$ & 0.570 & $\begin{array}{l}1.207(0.629- \\
2.316)\end{array}$ & 0.571 \\
\hline Other pathogens & $770(9.43)$ & $690(9.05)$ & $80(14.90)$ & $x^{2}=20.094$ & $\begin{array}{l}< \\
0.001\end{array}$ & $\begin{array}{l}1.760(1.370- \\
2.260)\end{array}$ & $<0.001$ \\
\hline 90-day mortality, n(\%) & $2009(24.61)$ & $1830(24.00)$ & 179 (33.33) & $x^{2}=23.569$ & $\begin{array}{l}< \\
0.001\end{array}$ & $\begin{array}{l}1.584(1.314- \\
1.909)\end{array}$ & $<0.001$ \\
\hline 180-day mortality, n(\%) & $2171(26.60)$ & $1969(25.82)$ & $202(37.62)$ & $x^{2}=35.762$ & $\begin{array}{l}< \\
0.001\end{array}$ & $\begin{array}{l}1.732(1.444- \\
2.078)\end{array}$ & $<0.001$ \\
\hline
\end{tabular}

RDW red cell distribution width, COPD chronic obstructive pulmonary disease, SOFA septicemia and heart failure, sequential organ failure assessment, WBC white blood cell, A.baumannii Acinetobacter baumannii, P.aeruginosa Pseudomonas aeruginosa, MRSA methicillin-resistant Staphylococcus aureus K.pneumoniae Klebsiella pneumonia, MSSA methicillin-sensitive Staphylo coccus aureus, E. coli Escherichia coli, SAPSIl simplified acute physiology score II

1.465, 95\%CI: 1.188-1.807, $P<0.001)$, and the 180-day mortality risk of VAP patients was 1.635 times $(\mathrm{OR}=$ 1.635, 95\%CI: $1.333-2.005, P<0.001)$ compared with those in non-VAP patients (Table 3, Fig. 2).

\section{Discussion}

This study collected the data of 8163 patients receiving MV in ICU from MIMIC III database to investigate the effect of VAP on the prognosis of patients within 90-day and 180-day. From the data we observed that the 90-day and 180-day mortality rates were higher in the VAP group than those in the non-VAP group.

Patients with severe illness are usually admitted into ICU and the mortality of patients in ICU was very high [17]. VAP is one of the common nosocomial infection in

Table 3 The association between VAP and 90/180-day mortality

\begin{tabular}{|c|c|c|c|c|}
\hline \multirow[t]{2}{*}{ Outcome } & \multicolumn{2}{|l|}{ Univariate } & \multicolumn{2}{|l|}{ Multivariate } \\
\hline & OR $(95 \% \mathrm{Cl})$ & $P$ & OR $(95 \% \mathrm{Cl})$ & $P$ \\
\hline
\end{tabular}

90-day mortality

VAP

No Ref Ref

Yes $1.584(1.314-1.910)<0.001 \quad 1.465(1.188-1.807)<0.001$

180-day mortality

VAP

No Ref Ref

Yes $1.733(1.445-2.079) \quad<\mathbf{0 . 0 0 1} 1.635(1.333-2.005) \quad<\mathbf{0 . 0 0 1}$

Confounders (Age, Ethnicity, Heart failure, Septicemia, SAPSII score, SOFA score, Serum Lactate, WBC, Length of ICU stay, Length of hospital stay, Length of ventilation, Antibiotic treatment, P.aeruginosa, MRSA, Other pathogens) were adjusted
ICU $[18,19]$. The occurrence of VAP occurs mainly due to the endotracheal tube for delivering MV. Endotracheal tube can produce irritation of the respiratory mucosa, and increase the amount of mucus [20, 21]. Currently, guidelines for preventing VAP were proposed in many studies, including hand washing, elevation of the head of the bed, oral antiseptics and antibiotics, use of endotracheal tubes with subglottic secretion aspiration ports and silver-coated endotracheal tubes, weaning protocols to early extubation, and bundles application, the incidence of VAP is still high [22].

VAP in ICU is associated with increased mortality, and the prognosis of those patients is poor [23]. A retrospective study by Feng et al. reported that in VAP patients, $24.8 \%$ were aged $>70$ years old and the 30-day mortality was as high as $42.8 \%$ [24]. In a study of Vallés et al., the data delineated that VAP is associated with excess mortality and the mortality of VAP patients were higher than that in non-VAP patients (45\% vs $27.0 \%)$ [25]. Another study indicated that the ICU mortality rate of patients with VAP was $32.5 \%$ and hospital mortality rate was $42.5 \%$, which was higher than those in patients without VAP and patients with other ICU-hospital-acquired pneumonias [26]. Kobayashi et al. also reported that the ICU mortality of VAP patients was about $25.0 \%$ compared with $13.9 \%$ in patients without VAP [27]. The findings of these studies were allied with the results of our study. Herein, we found the 90-day and 180-day mortality rates were higher in the VAP group than in the non-VAP group. The 90-day mortality risk of VAP patients was 1.465 times, and the 180-day mortality risk of VAP patients was 1.635 times than those in patients 


\section{Logistic Regression Forestplot}

\begin{tabular}{|c|c|c|c|c|c|c|c|c|}
\hline \multirow{2}{*}{ Outcome } & \multicolumn{2}{|c|}{ Model 1} & \multicolumn{3}{|c|}{ Model 2} & & & \\
\hline & OR $(95 \% C I)$ & Pvalue & OR $(95 \% C I)$ & Pvalue & & & & \\
\hline 90-day mortality & & & & & & & & Model 1 \\
\hline VAP & & & & & & & & Model 2 \\
\hline No & Ref & & Ref & & & & & \\
\hline Yes & $1.584(1.314-1.910)$ & $<0.001$ & $1.465(1.188-1.807)$ & $<0.001$ & & & $\Longrightarrow$ & $=$ \\
\hline 180-day mortality & & & & & & & & \\
\hline VAP & & & & & & & & \\
\hline No & Ref & & Ref & & & & & \\
\hline Yes & $1.733(1.445-2.079)$ & $<0.001$ & $1.635(1.333-2.005)$ & $<0.001$ & & & & $\longrightarrow$ \\
\hline $\begin{array}{r}\text { Note:Model 1: Single fact } \\
\text { Model 2: Adjustmen } \\
\text { WBC, Lens } \\
\text { P.aeruginos }\end{array}$ & $\begin{array}{l}\text { logistic regression analysis } \\
\text { Age, Ethnicity, Heart failure, } \\
\text { th of ICU stay, Length of hosp } \\
\text { a, MRSA, Other pathogens }\end{array}$ & $\begin{array}{l}\text { Septicemia, } \\
\text { pital stay, Ler }\end{array}$ & $\begin{array}{l}\text { SAPSII score, SOFA score, Se } \\
\text { ngth of ventilation, Antibiotic }\end{array}$ & $\begin{array}{l}\text { ierum Lactate, } \\
\text { treatment, }\end{array}$ & 1 & $\begin{array}{l}1 \\
1.2\end{array}$ & $\begin{array}{ll}1 & 1 \\
1.4 & 1.6 \\
\text { Odds Ratio }\end{array}$ & $\begin{array}{ll} \\
1.8\end{array}$ \\
\hline
\end{tabular}

without VAP. A high risk of mortality of VAP patients in ICU receiving $\mathrm{MV}$ indicated that to prevent the occurrence of VAP is of great importance. Factors including mechanical ventilation time, and use of antibiotics affected the occurrence of VAP [28], demonstrating appropriately use of $\mathrm{MV}$ and antibiotics was required in ICU patients. Previous studies also indicated that the comprehensive nursing intervention including traditional clinical nursing techniques, various examination measures, and drug intervention, as well as interventions to improve the cognition, psychological state and behavior in patients could prevent the occurrence of VAP, shorten the ventilation time, lower the lung damage and improve the prognosis [29]. Therefore, nurses in ICU should be more strictly trained to take care of these patients.

There were some strengths in our study. Firstly, this was a study with a large scale of sample size based on MIMIC III database, and the sample size was larger than previous studies. Secondly, we adjusted variables with statistical differences including age, ethnicity, heart failure, septicemia, SAPSII score, SOFA score, serum lactate, WBC, length of ICU stay, length of hospital stay, length of ventilation, antibiotic treatment, P.aeruginosa, MRSA, other pathogens between VAP group and nonVAP group, which might have more reliable results. Several limitations existed in this study. Compared with other studies, the variables could be collected from MIMIC III database were limited and incomprehensive, correlated variables including underlying diseases of patients and was not involved in. Additionally, CDC criteria was used to diagnose VAP, which might overestimate the incidence of VAP and this may cause the selection bias in patients. Multi-centers studies with more correlated variables should be conducted to support the conclusions of our study.

\section{Conclusions}

The present study evaluated the 90 -day or 180-day mortalities of ICU patients with VAP and the effect of VAP on the risk of mortality in patients. The results observed the poorer prognosis of patients with VAP in ICU than non-VAP patients. The findings of this study might have significant implications for increasing the knowledge of preventing the occurrence of VAP.

\section{Abbreviations}

MV: Mechanical ventilation; ICU: intensive care unit; VAP: ventilator-associated pneumonia; MIMIC III: Medical Information Mart for Intensive Care III;

RDW: red cell distribution width; SOFA: sequential organ failure assessment; CDC: Centers for Disease Control and Prevention; COPD: chronic obstructive pulmonary disease; WBC: white blood cell; A.baumannii: Acinetobacter baumannii; P.aeruginosa: Pseudomonas aeruginosa; MRSA: methicillin-resistant Staphylococcus aureus; K.pneumoniae: Klebsiella pneumonia;

MSSA: methicillin-sensitive Staphylo coccus aureus; E. coli: Escherichia colli;

SAPSII: simplified acute physiology score II

Acknowledgements

We thank the participants included in our study for their contributions.

\section{Authors' contributions}

WJ Luo designed the study and wrote the manuscript. R Xing and CM Wang collected, analyzed and interpreted the data. WJ Luo critically reviewed, edited and approved the manuscript. All authors read and approved the final manuscript.

\section{Funding}

None.

Availability of data and materials

The datasets generated and/or analyzed during the current study are available from the corresponding author on reasonable request. 


\section{Declarations}

Ethics approval and consent to participate

Not applicable.

\section{Consent for publication}

Not applicable.

\section{Competing interests}

The authors declare that they have no competing interests.

Received: 8 March 2021 Accepted: 17 June 2021

Published online: 15 July 2021

\section{References}

1. Gutiérrez JMM, Borromeo AR, Dueño AL, Paragas ED Jr, Ellasus RO, AbalosFabia RS, et al. Clinical epidemiology and outcomes of ventilator-associated pneumonia in critically ill adult patients: protocol for a large-scale systematic review and planned meta-analysis. Syst Rev. 2019;8(1):180. https://doi.org/10.1186/s13643-019-1080-y.

2. Mutlu GM, Factor P. Complications of mechanical ventilation. Respir Care Clin N Am. 2000;6(2):213-52,v. https://doi.org/10.1016/S1078-533 7(05)70069-1.

3. Kalil AC, Metersky ML, Klompas M, Muscedere J, Sweeney DA, Palmer LB, et al. Management of Adults with Hospital-acquired and Ventilatorassociated Pneumonia: 2016 clinical practice guidelines by the Infectious Diseases Society of America and the American Thoracic Society. Clin Infect Dis. 2016;63(5):e61-111. https://doi.org/10.1093/cid/ciw353.

4. American Thoracic Society; Infectious Diseases Society of America. Guidelines for the management of adults with hospital-acquired, ventilatorassociated, and healthcare-associated pneumonia. Am J Respir Crit Care Med. 2005;171:388-416.

5. Sulis CA, Walkey AJ, Abadi Y, Campbell Reardon C, Joyce-Brady M. Outcomes of a ventilator-associated pneumonia bundle on rates of ventilator-associated pneumonia and other health care-associated infections in a long-term acute care hospital setting. Am J Infect Control. 2014;42(5): 536-8. https://doi.org/10.1016/j.ajic.2014.01.020.

6. Torres A, Niederman MS, Chastre J, Ewig S, Fernandez-Vandellos P, Hanberger $\mathrm{H}$, et al. International ERS/ESICM/ESCMID/ALAT guidelines for the management of hospital-acquired pneumonia and ventilator-associated pneumonia: Guidelines for the management of hospital-acquired pneumonia (HAP)/ventilator-associated pneumonia (VAP) of the European Respiratory Society (ERS), European Society of Intensive Care Medicine (ESIC M), European Society of Clinical Microbiology and Infectious Diseases (ESCM ID) and Asociación Latinoamericana del Tórax (ALAT). Eur Respir J. 2017;50.

7. Vincent JL, de Souza BD, Cianferoni S. Diagnosis, management and prevention of ventilator-associated pneumonia: an update. Drugs. 2010; 70(15):1927-44. https://doi.org/10.2165/11538080-000000000-00000.

8. Inchai J, Pothirat C, Liwsrisakun C, Deesomchok A, Kositsakulchai W, Chalermpanchai N. Ventilator-associated pneumonia: epidemiology and prognostic indicators of 30-day mortality. Jpn J Infect Dis. 2015;68(3):181-6. https://doi.org/10.7883/yoken.JJID.2014.282.

9. Xie DS, Xiong W, Lai RP, Liu L, Gan XM, Wang XH, et al. Ventilator-associated pneumonia in intensive care units in Hubei Province, China: a multicentre prospective cohort survey. J Hosp Infect. 2011;78(4):284-8. https://doi.org/1 0.1016/j.jhin.2011.03.009.

10. Huang Y, Jiao Y, Zhang J, Xu J, Cheng Q, Li Y, et al. Microbial etiology and prognostic factors of ventilator-associated pneumonia: a multicenter retrospective study in Shanghai. Clin Infect Dis. 2018;67(suppl_2):S146-52. https://doi.org/10.1093/cid/ciy686.

11. Wei $Y$, Huang $H$, Zhang R, Zhu Z, Zhu Y, Lin L, et al. Association of Serum Mannose with Acute Respiratory Distress Syndrome Risk and Survival. JAMA Netw Open. 2021;4(1):e2034569. https://doi.org/10.1001/jamanetworkopen.2 020.34569 .

12. Melsen WG, Rovers MM, Groenwold RH, Bergmans DC, Camus C, Bauer TT, et al. Attributable mortality of ventilator-associated pneumonia: a metaanalysis of individual patient data from randomised prevention studies. Lancet Infect Dis. 2013;13(8):665-71. https://doi.org/10.1016/S1473-3099(13 )70081-1.
13. Papazian $L$, Klompas M, Luyt CE. Ventilator-associated pneumonia in adults: a narrative review. Intensive Care Med. 2020;46(5):888-906. https://doi.org/1 0.1007/s00134-020-05980-0.

14. Johnson AE, Pollard TJ, Shen L, Lehman LW, Feng M, Ghassemi M, et al. MIMIC-III, a freely accessible critical care database. Sci Data. 2016;3(1):160035. https://doi.org/10.1038/sdata.2016.35.

15. Magill SS, Klompas M, Balk R, Burns SM, Deutschman CS, Diekema D, et al. Developing a new, national approach to surveillance for ventilatorassociated events. Am J Crit Care. 2013;22(6):469-73. https://doi.org/10.403 7/ajcc2013893.

16. Klompas M, Magill S, Robicsek A, Strymish JM, Kleinman K, Evans RS, et al. Objective surveillance definitions for ventilator-associated pneumonia. Crit Care Med. 2012;40(12):3154-61. https://doi.org/10.1097/CCM.0b013e3182 $60 c 6 \mathrm{~d} 9$.

17. Yang Q, Du JL, Shao F. Mortality rate and other clinical features observed in open vs closed format intensive care units: a systematic review and metaanalysis. Medicine (Baltimore). 2019;98(27):e16261. https://doi.org/10.1097/ MD.0000000000016261.

18. Planquette B, Timsit JF, Misset BY, Schwebel C, Azoulay E, Adrie C, et al. Pseudomonas aeruginosa ventilator-associated pneumonia. Predictive factors of treatment failure. Am J Respir Crit Care Med. 2013;188(1):69-76. https://doi.org/10.1164/rccm.201210-18970C.

19. Li B, Han S, Liu F, Kang L, Xv C. Budesonide nebulization in the treatment of neonatal ventilator associated pneumonia. Pak J Med Sci. 2017;33(4):9971001. https://doi.org/10.12669/pjms.334.12907.

20. Hunter JD. Ventilator associated pneumonia. BMJ. 2012;344(may29 1):e3325. https://doi.org/10.1136/bmj.e3325.

21. Cardeñosa Cendrero JA, Solé-Violán J, Bordes Benítez A, Noguera Catalán J, Arroyo Fernández J, Saavedra Santana P, et al. Role of different routes of tracheal colonization in the development of pneumonia in patients receiving mechanical ventilation. Chest. 1999;116(2):462-70. https://doi.org/1 0.1378/chest.116.2.462.

22. Oliveira J, Zagalo C, Cavaco-Silva P. Prevention of ventilator-associated pneumonia. Rev Port Pneumol. 2014;20(3):152-61. https://doi.org/10.1016/j. rppneu.2014.01.002.

23. Mahmoodpoor A, Hamishehkar H, Asghari R, Abri R, Shadvar K, Sanaie S. Effect of a probiotic preparation on ventilator-associated pneumonia in critically ill patients admitted to the intensive care unit: a prospective double-blind randomized controlled trial. Nutr Clin Pract. 2019;34(1):156-62. https://doi.org/10.1002/ncp.10191.

24. Feng DY, Zhou YQ, Zhou M, Zou XL, Wang YH, Zhang TT. Risk factors for mortality due to ventilator-associated pneumonia in a Chinese hospital: a retrospective study. Med Sci Monit. 2019;25:7660-5. https://doi.org/10.12 659/MSM.916356

25. Vallés J, Pobo A, García-Esquirol O, Mariscal D, Real J, Fernández R. Excess ICU mortality attributable to ventilator-associated pneumonia: the role of early vs late onset. Intensive Care Med. 2007;33(8):1363-8. https://doi.org/1 0.1007/s00134-007-0721-0.

26. Ibn Saied W, Mourvillier B, Cohen Y, Ruckly S, Reignier J, Marcotte G, et al. A comparison of the mortality risk associated with ventilator-acquired bacterial pneumonia and nonventilator ICU-acquired bacterial pneumonia. Crit Care Med. 2019;47(3):345-52. https://doi.org/10.1097/CCM. 0000000000003553

27. Kobayashi H, Uchino S, Takinami M, Uezono S. The impact of ventilatorassociated events in critically ill subjects with prolonged mechanical ventilation. Respir Care. 2017;62(11):1379-86. https://doi.org/10.4187/respca re.05073.

28. Kollef MH, Hamilton CW, Ernst FR. Economic impact of ventilator-associated pneumonia in a large matched cohort. Infect Control Hosp Epidemiol. 2012; 33(3):250-6. https://doi.org/10.1086/664049.

29. Fan $Y$, Chu $X$, Jiang $L$, Du $X$. The clinical value of comprehensive nursing intervention in preventing ventilator-associated pneumonia. Am J Transl Res. 2021;13(4):3845-50.

\section{Publisher's Note}

Springer Nature remains neutral with regard to jurisdictional claims in published maps and institutional affiliations. 